\title{
The Effect of Paclobutrazol Application Time and Variety on Growth, Yield, and Quality of Potato (Solanum tuberosum L.)
}

\author{
Ottilia Mabvongwe, ${ }^{1}$ Brenda T. Manenji, ${ }^{2}$ \\ Munyaradzi Gwazane, ${ }^{2}$ and Misheck Chandiposha ${ }^{2}$ \\ ${ }^{1}$ Ministry of Agriculture, Mechanization and Irrigation Development, No. 1 Borrowdale Road, Ngungunyana Building, \\ Harare, Zimbabwe \\ ${ }^{2}$ Department of Agronomy, Midlands State University, Private Bag Box 9055, Gweru, Zimbabwe \\ Correspondence should be addressed to Misheck Chandiposha; chandiposham@msu.ac.zw
}

Received 2 December 2015; Accepted 11 January 2016

Academic Editor: Tibor Janda

Copyright (C) 2016 Ottilia Mabvongwe et al. This is an open access article distributed under the Creative Commons Attribution License, which permits unrestricted use, distribution, and reproduction in any medium, provided the original work is properly cited.

An experiment was set up to investigate the effect of time of paclobutrazol application and variety on growth, yield, and quality of potato in a greenhouse at $34^{\circ} \mathrm{C}( \pm 3)$ and $21^{\circ} \mathrm{C}( \pm 3)$ day and night temperatures, respectively, with $60 \%$ relative humidity. The experiment was set up as a $2 \times 4$ factorial design in a CRD with 3 replications. The first factor was potato variety and the levels were BP1 and Diamond. The second factor was paclobutrazol application time and the levels were 28 (Days After Planting) DAP, $35 \mathrm{DAP}$, and $42 \mathrm{DAP}$ and no paclobutrazol applied (control). Early application of paclobutrazol reduced stem length, number of tubers per plant, and sugar content of potato; furthermore, it increased starch content and yield compared to late application and no paclobutrazol treatments. Early application of paclobutrazol at $28 \mathrm{DAP}$ is recommended in high temperature zones as it increased the yield by $108 \%$ and quality of potato.

\section{Introduction}

Potato is a cool season crop and the optimum temperature requirements for tuber development have been reported to be in the range of $14-22^{\circ} \mathrm{C}$ [1]. Potato production has been limited to cool regions in Zimbabwe and yet the country has more than $43 \%$ of semiarid area [2]. To increase food and nutrition security in the country, it is imperative to grow potatoes in high temperature regions. High temperatures cause a reduction in the rate of photosynthesis, translocation of assimilates to tubers, and conversion rate of sucrose into starch resulting in limited tuber formation and growth [3]. The yield reduction at high temperatures is partly due to reduced assimilate partitioning and delayed tuber initiation [4]. At high temperatures, foliage growth is vigorous and considerable amounts of carbohydrates are utilized for foliage growth at the expense of tuberization [5].

The total dry matter production and its distribution to the different plant organs is an important factor affecting tuber yield in potato [6]. The transition of a stolon into a tuber at high temperatures is limited as there is an increase in the level of gibberellic acid in leaf buds limiting tuber production [3]. High levels of gibberellic acid lead to higher carbohydrate allocation to shoots at the expense of tubers [5].

One of the attempts to increase potato productivity in tropical climates where high temperatures are experienced is the use of plant growth regulators such as paclobutrazol [3]. The mode of action of paclobutrazol is the inhibition of gibberellic acid synthesis in plants. The inhibition of gibberellin production by paclobutrazol results in slow cell division and elongation without causing toxicity to cells [7].

Application time of paclobutrazol may affect potato yield in high temperature areas. Paclobutrazol treatment of potato plants promoted tuberization in vitro and under greenhouse conditions with cultivar response to the timing of treatment [8]. Tuberization is a continuous process and all the different developmental stages from stolon induction to tuber growth may occur at one plant but not all tubers will be able to 
develop to usable tubers at harvest time [9]. The continuous appearance of stolons during tuber bulking period may not contribute to the number of tubers harvested as each variety has a time when stolon swelling ceases [10] and therefore timing of paclobutrazol application is critical.

Application of plant growth regulators at tuber initiation can alter photosynthetic partitioning in favour of tuber production and increase yields [7]. Celis-Gamboa et al. [11] found out that stolon formation occurred 29 DAP and the stolon tip swelling started from 29 to 36 DAP for the cultivars that were under study. Tubers that overly attain the greatest weight are usually produced by the lowest stolons and are formed at the beginning of tuber development [10]. However, there is limited information on the appropriate time of paclobutrazol application using our local varieties to maximise yield and quality of potato tubers under conditions of high temperatures.

\section{Materials and Methods}

2.1. Research Site and Characteristics. The research was carried out at Harare Research Station $\left(31^{\circ} 03^{\prime} \mathrm{E}\right.$ and $\left.17^{\circ} 48^{\prime} \mathrm{S}\right)$. It is located within agroecological region IIa with an altitude of $1506 \mathrm{~m}$ above sea level. The research station receives annual rainfall of $820 \mathrm{~mm}$. The experiment was conducted in a greenhouse and the day temperature was $34^{\circ} \mathrm{C}( \pm 3)$ and the night temperature was $21^{\circ} \mathrm{C}( \pm 3)$. The average relative humidity in the greenhouse was $60 \%$. The experiment was set up in April to July 2014 and day length was characterised by short days and long nights.

2.1.1. Experimental Design and Treatments. The experiment was set up as a $4 \times 2$ factorial in a complete randomized design with 3 replications. The first factor was time of paclobutrazol application and the second factor was variety with the levels shown in Table 1.

2.1.2. Plant Culture. Two varieties of potato seed Diamond and BP1 were left to sprout in a dark room until the sprouts were about $2 \mathrm{~cm}$ in length. The sprouted seed tubers were then transferred to a room with diffuse light to harden sprouts for two weeks until the sprouts turned from white to green. The soils used for planting were predominantly red clays. Planting was done in $20 \mathrm{~L}$ black plastic pockets that were $50 \mathrm{~cm} \times 40 \mathrm{~cm}$. The pockets were initially half filled with soil to a height of $25 \mathrm{~cm}$. Basal fertilizer was applied at a rate of $2000 \mathrm{~kg} / \mathrm{ha}$ Compound S $(7: 21: 7)$ and was incorporated into the pockets. Planting holes that were $10 \mathrm{~cm}$ deep were dug in each pocket and 1 tuber was placed in each pocket, covered with soil, and irrigated. One experimental unit was comprised of 5 pots.

Top dressing was done at four weeks after emergence using Ammonium Nitrate $(34.5 \% \mathrm{~N})$ at a rate of $200 \mathrm{~kg} / \mathrm{ha}$. Earthing up was done by filling up the pockets with the same soil that was used at planting. Preventative sprays for blights were done on a weekly basis using copper oxychloride. Weeding was done by pulling the weeds by hand from the pockets whilst they were still young. Watering was done when necessary depending on the stage of crop growth. Harvesting of the tubers was done after 120 DAP.
TABLE 1: Treatment structure for the effect of time of paclobutrazol application on growth, quality, and yield of potato.

\begin{tabular}{|c|c|c|}
\hline Treatment & Variety & $\begin{array}{c}\text { Time of paclobutrazol } \\
\text { application }\end{array}$ \\
\hline 1 & BP1 & 28 \\
\hline 2 & BP1 & 35 \\
\hline 3 & BP1 & 42 \\
\hline 4 & BP1 & $\begin{array}{l}\text { No paclobutrazol } \\
\quad(\text { control })\end{array}$ \\
\hline 5 & Diamond & 28 \\
\hline 6 & Diamond & 35 \\
\hline 7 & Diamond & 42 \\
\hline 8 & Diamond & $\begin{array}{c}\text { No paclobutrazol } \\
\text { (control) }\end{array}$ \\
\hline
\end{tabular}

2.1.3. Treatment Application. Paclobutrazol 29.9\% active ingredient was applied at a rate of $250 \mathrm{~g} / \mathrm{ha}$ and was applied at 28, 35, and 42 DAP according to treatment structure shown in Table 1. A 15 litre knapsack sprayer was used for spraying to attain full cover spray.

2.1.4. Measurements and Data Analysis. Measurements taken included stem diameter at the base and length on two randomly sampled plants per experimental unit at 49 and 63 DAP, number of tubers per plant, yield, starch content, reducing sugar content of potato tubers [12], and grades of potato at the end of the experiment (120 DAP). The grades of potato were divided into small $(56-63.9 \mathrm{~mm})$, medium (64-75.9 mm), large (76-83.9 $\mathrm{mm})$, and extra large (>84 $\mathrm{mm}$ diameter). Analysis of variance of data was done using Genstat Version 14. Treatment means were separated using the LSD at $5 \%$ level of significance.

\section{Results and Discussion}

3.1. Effect of Time of Paclobutrazol Application on Potato Stem Length $(\mathrm{cm})$ at 49 and 63 DAP. Paclobutrazol treatment at 28 DAP resulted in stems that were shorter compared to delay in application of the growth regulator and no paclobutrazol treatments at 49 and 63 DAP (Table 2). Probably early application of paclobutrazol quickly arrested the activity of gibberellic acid inside plant cells which are responsible for stem elongation, hence reducing the length of stems. Gibberellic acid is responsible for stem elongation by increasing the internode length [13]. Paclobutrazol reduces the level of gibberellic acid inside plant cells by interfering with the oxidative steps of gibberellin precursor ent-kauren to entkaurenic acid blocking the synthesis of gibberellins in the early step of its biosynthetic pathway $[14,15]$. These results are similar to findings by Bandara et al. [8] that application of paclobutrazol at early tuber initiation reduces the haulm growth significantly compared to when it is applied at late stolon initiation.

3.2. Effect of Time of Paclobutrazol Application on Potato Stem Diameter $(\mathrm{cm})$ at 49 and 63 DAP. Early application 
TABLE 2: Effect of time of paclobutrazol application on potato stem length $(\mathrm{cm})$ at 49 and 63 DAP.

\begin{tabular}{lcc}
\hline $\begin{array}{l}\text { Time of paclobutrazol } \\
\text { application (DAP) }\end{array}$ & \multicolumn{2}{c}{ Stem length $(\mathrm{cm})$} \\
\hline 28 & 49 DAP & 63 DAP \\
35 & $41.67^{\mathrm{a}}$ & $44.33^{\mathrm{a}}$ \\
42 & $48.33^{\mathrm{b}}$ & $52.17^{\mathrm{b}}$ \\
No paclobutrazol & $55.50^{\mathrm{c}}$ & $58.33^{\mathrm{c}}$ \\
\hline$P$ value & $61.33^{\mathrm{d}}$ & $74.00^{\mathrm{d}}$ \\
\hline LSD & $<0.001$ & $<0.001$ \\
\hline
\end{tabular}

Means with the same letters in each column are not statistically different at $5 \%$ significance level.

TABLE 3: Effect of time of paclobutrazol application on potato stem diameter $(\mathrm{cm})$ at 49 and 63 DAP.

\begin{tabular}{lcc}
\hline $\begin{array}{l}\text { Time of paclobutrazol } \\
\text { application (DAP) }\end{array}$ & \multicolumn{2}{c}{ Stem diameter $(\mathrm{cm})$} \\
\hline 28 & 49 DAP & 63 DAP \\
35 & $1.173^{\mathrm{a}}$ & $1.643^{\mathrm{a}}$ \\
42 & $1.057^{\mathrm{b}}$ & $1.455^{\mathrm{b}}$ \\
No paclobutrazol & $0.975^{\mathrm{c}}$ & $1.378^{\mathrm{c}}$ \\
\hline$P$ value & $0.892^{\mathrm{d}}$ & $0.940^{\mathrm{d}}$ \\
LSD & $<0.001$ & $<0.001$ \\
\hline
\end{tabular}

Means with the same letters in each column are not statistically different at $5 \%$ significance level.

of paclobutrazol resulted in thicker and more compact stems than late application and no paclobutrazol treatments (Table 3). Similarly, early application of paclobutrazol increased the diameter of stems considerably compared to late applications. This may be explained by the low levels of gibberellic acid after early application of paclobutrazol as high levels of gibberellic acid limit radial expansion of plant organs [16]. Probably the reduction in stem length due to early application of paclobutrazol compared to late application of paclobutrazol may have resulted in increases in stem diameter for the former compared to the later. Paclobutrazol treatment increases the thickness of cortex, vascular bundles, and pith diameter resulting in thicker stems [17].

\subsection{Effect of Time of Paclobutrazol Application on Total Num-} ber of Potato Tubers per Plant. Significant differences $(P<$ $0.05)$ in time of paclobutrazol application were observed with respect to total number of tubers per plant. The least number of potato tubers was recorded in plots where paclobutrazol was applied at $28 \mathrm{DAP}$ although it was not significantly different from 35 DAP (Figure 1). The reduction in the number of tubers per plant may be attributed to decrease in the number of stolons due to low levels of gibberellic acid after paclobutrazol application. The fewer numbers of stolons resulted in fewer numbers of tubers as they are formed after the differentiation of stolons into vegetative storage organs. These results agree with the findings by Vreugdenhil and Sergeeva [5] that application of gibberellic acid reduces number of tubers per plant.

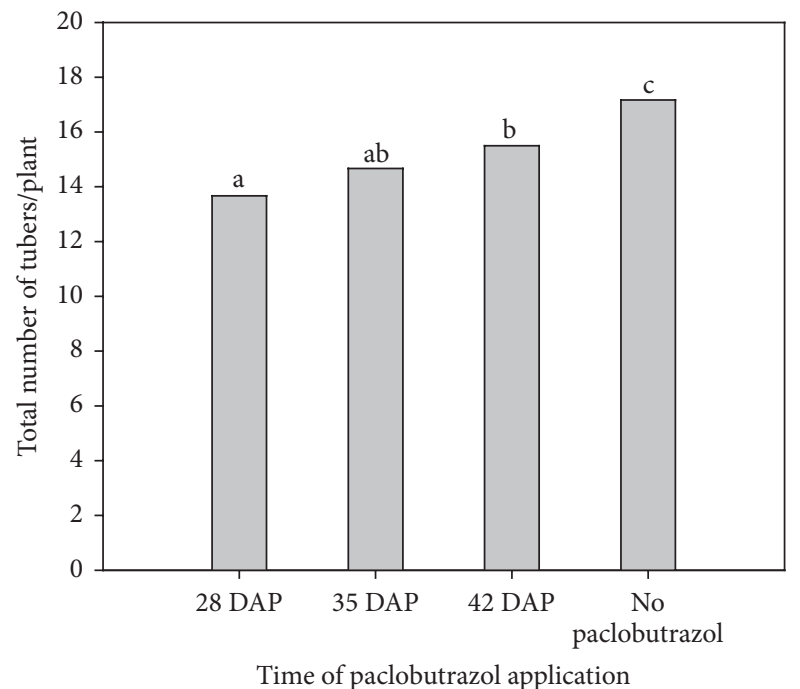

FIGURE 1: Effect of time of paclobutrazol application on total number of potato tubers per plant.

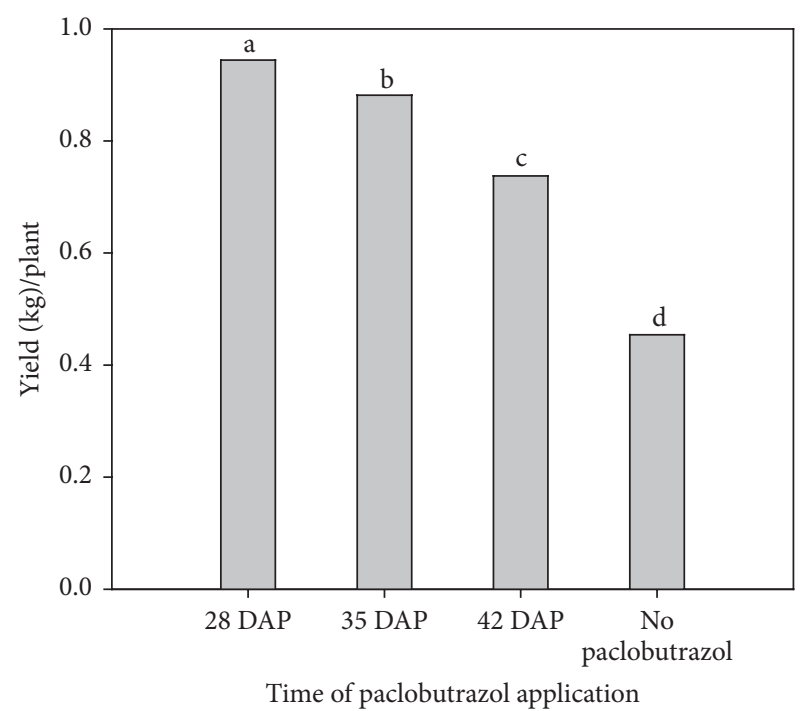

FIGURE 2: Effect of time of paclobutrazol application on potato tuber yield $(\mathrm{kg})$ per plant.

\subsection{Effect of Time of Paclobutrazol Application on Potato Yield} $(\mathrm{kg} /$ Plant). The highest potato yield was observed in treatments where paclobutrazol was applied at 28 DAP. Yield of about $108 \%$ was recorded in early application when compared to no paclobutrazol treatments (Figure 2). The increase in yield may have been caused by the reduction of stem length that was observed in the experiment as more assimilates were channelled to tuber growth increasing yield [6]. The increase in yield in treatments where paclobutrazol was applied early may also be explained by early tuberization due to low levels of gibberellic acid. Application of paclobutrazol coinciding with tuber initiation resulted in more yields compared to application of paclobutrazol at late tuber initiation $[8,10]$.

3.5. Effect of Time of Paclobutrazol Application on Potato Tuber Grades per Plant. Plants treated with paclobutrazol at 28 and 
TABLE 4: Effect of time of paclobutrazol application on potato tuber grades as per plant.

\begin{tabular}{lcccc}
\hline $\begin{array}{l}\text { Time of paclobutrazol } \\
\text { application in DAP }\end{array}$ & Extra large & Large & Medium & Small \\
\hline 28 & $5.167^{\mathrm{a}}$ & $4.500^{\mathrm{a}}$ & $2.500^{\mathrm{a}}$ & $1.500^{\mathrm{a}}$ \\
35 & $3.333^{\mathrm{b}}$ & $3.833^{\mathrm{a}}$ & $4.500^{\mathrm{b}}$ & $3.000^{\mathrm{b}}$ \\
42 & $2.333^{\mathrm{c}}$ & $3.000^{\mathrm{b}}$ & $5.333^{\mathrm{c}}$ & $4.833^{\mathrm{c}}$ \\
No paclobutrazol & $0.000^{\mathrm{d}}$ & $1.667^{\mathrm{c}}$ & $7.000^{\mathrm{d}}$ & $8.500^{\mathrm{d}}$ \\
\hline$P$ value & $<0.001$ & $<0.001$ & $<0.001$ & $<0.001$ \\
LSD & 0.661 & 0.79 & 0.707 & 0.707 \\
\hline
\end{tabular}

Means with the same letters in each column are not statistically different at $5 \%$ significance level.

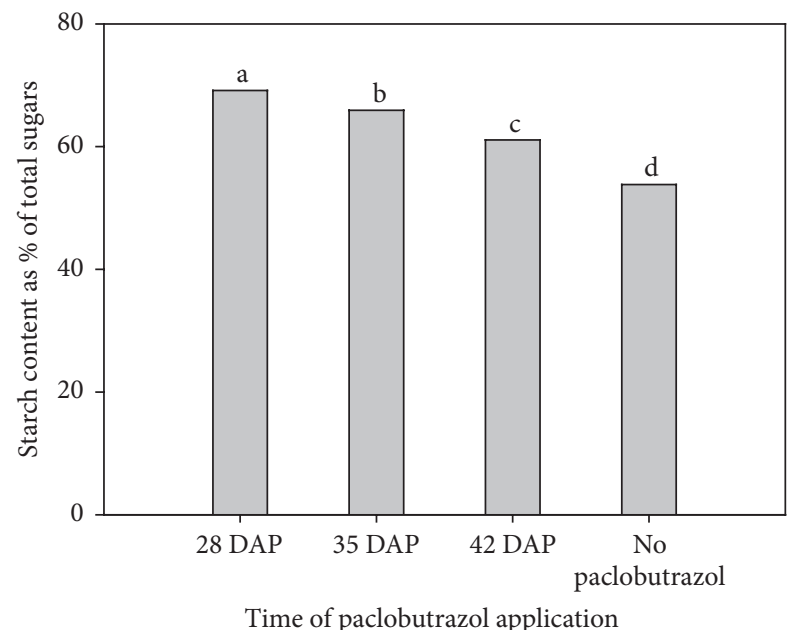

FIGURE 3: Effect of time of paclobutrazol application on potato tuber starch content as a $\%$ of sugars.

35 DAP had the biggest number of extra large and large tubers (Table 4). The increase in sizes of tubers may be as a result of low competition for assimilates since the early applied paclobutrazol plants had less numbers of tubers as shown in Figure 1 . These results may also be explained by the reduction in stem length for early paclobutrazol treatments and hence more assimilates were partitioned to tuber growth compared to haulm growth resulting in increased size of tubers. The increase in potato size may also be linked to early tuberization in plants treated with paclobutrazol at 28 and 35 DAP [6].

\subsection{Effect of Time of Paclobutrazol Application on Potato Tuber} Starch Content as a \% of Sugars. Application of paclobutrazol 28 DAP resulted in $28 \%$ increase in tuber starch content compared with treatments where paclobutrazol was not applied (Figure 3). The increase in starch content with early paclobutrazol application might have been caused by higher sink strength as evident on the increase in tuber size indicated by tuber grades shown in Table 4 enhancing starch synthesis and accumulation due to low levels of gibberellic acid. High levels of gibberellic acid during tuberization impede starch accumulation and hence low levels of starch in plants where paclobutrazol was not applied. The increase in starch content

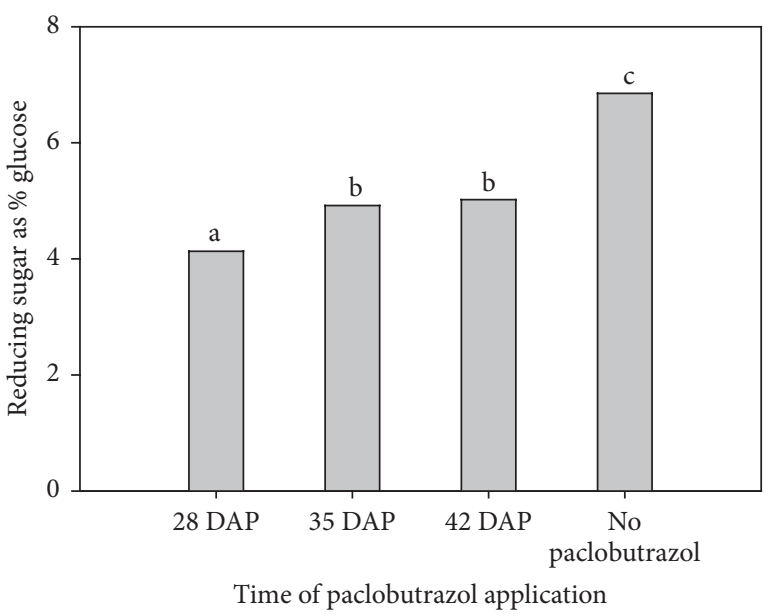

FIGURE 4: Effect of time of paclobutrazol application on potato tuber reducing sugar content as \% glucose.

in early applied paclobutrazol plants may also have been caused by early tuberization. Early paclobutrazol applied plants had more time to attract assimilates resulting in increase in starch content compared to the late application. Treatment of plants with paclobutrazol causes an increase in the number of enzymes that are responsible for starch biosynthesis such as starch synthase, therefore increasing starch content in tubers [9]. Application of paclobutrazol results in increased starch synthesis and accumulation in tubers [17] and hence increased starch content in all plants where paclobutrazol was applied. The least starch content was recorded in tubers where paclobutrazol was not applied and this can be explained by high levels of gibberellins that impede starch accumulation in tubers.

3.7. Effect of Time of Paclobutrazol Application on Potato Tuber Reducing Sugar Content as \% Glucose. The levels of reducing sugars were the lowest in plants treated with paclobutrazol at 28 DAP (Figure 4). The reduction in reducing sugar content may have been caused by increase in starch content in this treatment implying that most of the reducing sugars were converted to starch. This may be explained by low levels of gibberellic acid that stimulates enzymes such as starch synthase and starch biosynthesis that convert sugars to starch [9].

\section{Conclusions}

Early application of paclobutrazol at 28 DAP reduced the stem length and increased the stem diameter by $40 \%$ and $74 \%$, respectively. Early application of paclobutrazol reduced the total number of tubers per plant and increased potato tuber yield. Late application of paclobutrazol at $42 \mathrm{DAP}$ increased tuber reducing sugar content, reduced the grades of tubers, and decreased tuber starch content.

\section{Conflict of Interests}

The authors declare that there is no conflict of interests regarding the publication of this paper. 


\section{Acknowledgments}

The authors also want to thank Dr. D. Rukuni for his assistance in coming up with the project proposal. Many thanks are due to the Department of Research and Specialist Services and Ms. O Mavhangeni in particular for allocating greenhouse space to carry out the project.

\section{References}

[1] R. Schafleiter, M. Bonierbale, and D. Tay, "Applying photosynthesis research to improvement of food crops," in Proceedings of the International Lobster Aquaculture Symposium (ACIAR '13), vol. 140, pp. 52-59, Medan, Indonesia, November 2013.

[2] C. Gore, Y. Katerere, and S. Moyo, The Case for Sustainable Development in Zimbabwe Conceptual Problems, Conflicts and Contradictions, ENDA-Zimbabwe and ZERO, Harare, Zimbabwe, 1992.

[3] M. Rossanna, B. Mustafa, and L. Eny, "The effectiveness of paclobutrazol and organic fertilizer for the growth and yield of potatoes in medium plain," International Journal of Scientific \& Technology Research, vol. 3, no. 7, pp. 101-108, 2014.

[4] J. Van Dam, P. L. Kooman, and P. C. Struik, "Effects of temperature and photoperiod on early growth and final number of tubers in potato (Solanum tuberosum L.)," Potato Research, vol. 39, no. 1, pp. 51-62, 1996.

[5] D. Vreugdenhil and L. I. Sergeeva, "Gibberellins and tuberization in potato," Potato Research, vol. 42, no. 3-4, pp. 471-481, 1999.

[6] V. Balamani and B. W. Poovaiah, "Retardation of shoot growth and promotion of tuber growth of potato plants by paclobutrazol," American Potato Journal, vol. 62, no. 7, pp. 363-369, 1985.

[7] S. Manjula, S. Bandara, K. Tanino, and D. R. Waterer, "Effect of plant growth regulators on seed tuber yield in potatoes," Journal of Plant Growth Regulation, vol. 34, pp. 67-78, 1999.

[8] M. S. Bandara, K. K. Tanino, and D. R. Waterer, "Effect of pot size and timing of plant growth regulator treatments on growth and tuber yield in greenhouse-grown Norland and Russet Burbank potatoes," Journal of Plant Growth Regulation, vol. 17, no. 2, pp. 75-79, 1998.

[9] N. J. G. Appeldoorn, S. M. De Bruijn, E. A. M. Koot-Gronsveld, R. G. F. Visser, D. Vreugdenhil, and L. H. W. Van der Plas, "Developmental changes of enzymes involved in conversion of sucrose to hexose-phosphate during early tuberisation of potato," Planta, vol. 202, no. 2, pp. 220-226, 1997.

[10] D. Levy and R. E. Veilleux, "Adaptation of potato to high temperatures and salinity-a review," American Journal of Potato Research, vol. 84, no. 6, pp. 487-506, 2007.

[11] C. Celis-Gamboa, P. C. Struik, E. Jacobsen, and R. G. F. Visser, "Temporal dynamics of tuber formation and related processes in a crossing population of potato (Solanum tuberosum)," Annals of Applied Biology, vol. 143, no. 2, pp. 175-186, 2003.

[12] L. S. Munson and P. H. Walker, "The unification of reducing sugar methods," Journal of the American Chemical Society, vol. 28, no. 6, pp. 663-686, 1906.

[13] T. D. Davis, E. A. Curry, and G. L. Steffens, "Chemical regulation of vegetative growth," Critical Reviews in Plant Sciences, vol. 10, no. 2, pp. 151-188, 1991.

[14] P. Hedden and J. E. Graebe, "Inhibition of gibberellins biosynthesis by paclobutrazol in cell-free homogenates of Curcubita maxima endosperm and Malus pumila embryos," Plant Growth Regulation, vol. 4, no. 1, pp. 111-112, 1985.
[15] J. Latimer and B. Whipker, Using Piccolo with Herbaceous Perennials, edited by: Fine America, 2007.

[16] C. L. Wenzel, R. E. Williamson, and G. O. Wasteneys, "Gibberellin-induced changes in growth anisotropy precede gibberellindependent changes in cortical microtubule orientation in developing epidermal cells of barley leaves. Kinematic and cytological studies on a gibberellin-responsive dwarf mutant, M489," Plant Physiology, vol. 124, no. 2, pp. 813-822, 2000.

[17] T. Tsegaw, S. Hammes, and J. Robbertse, "Paclobutrazol-induced leaf, stem, and root anatomical modifications in potato," HortScience, vol. 40, no. 5, pp. 1343-1346, 2005. 


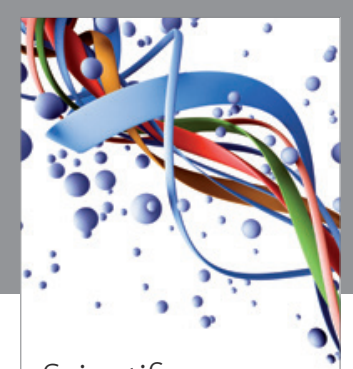

Scientifica
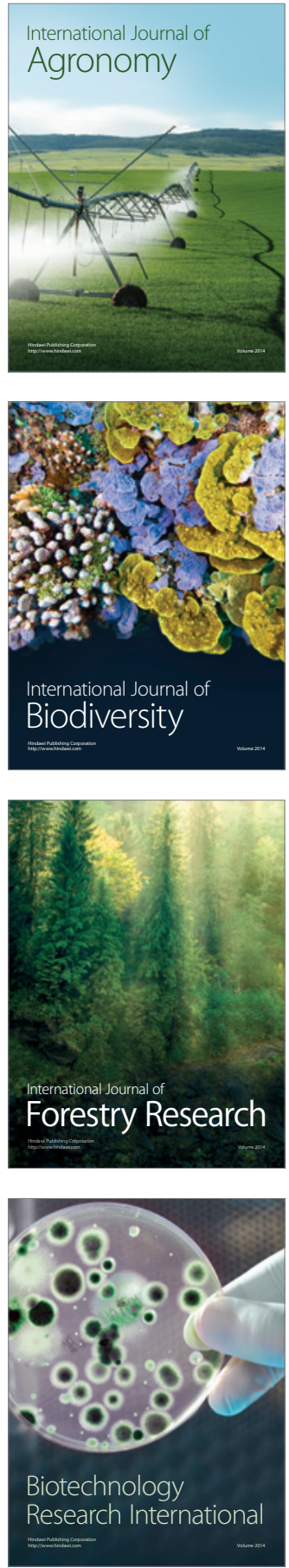
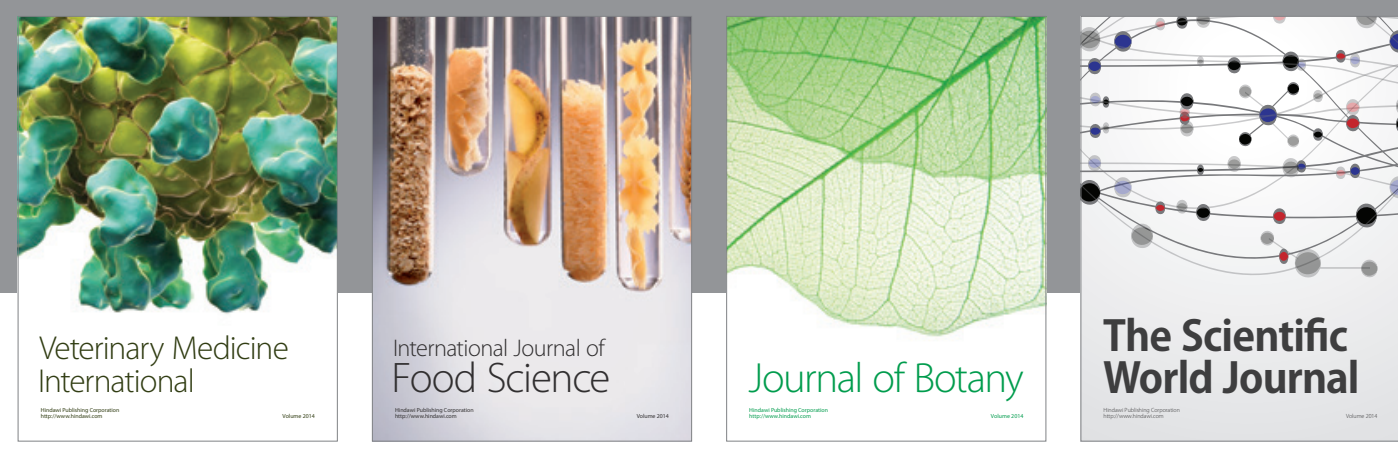

The Scientific

\section{World Journal}

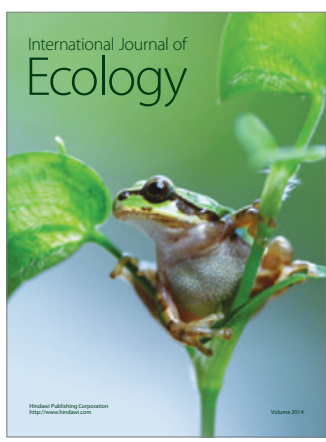

\section{Hindawi}

Submit your manuscripts at

http://www.hindawi.com
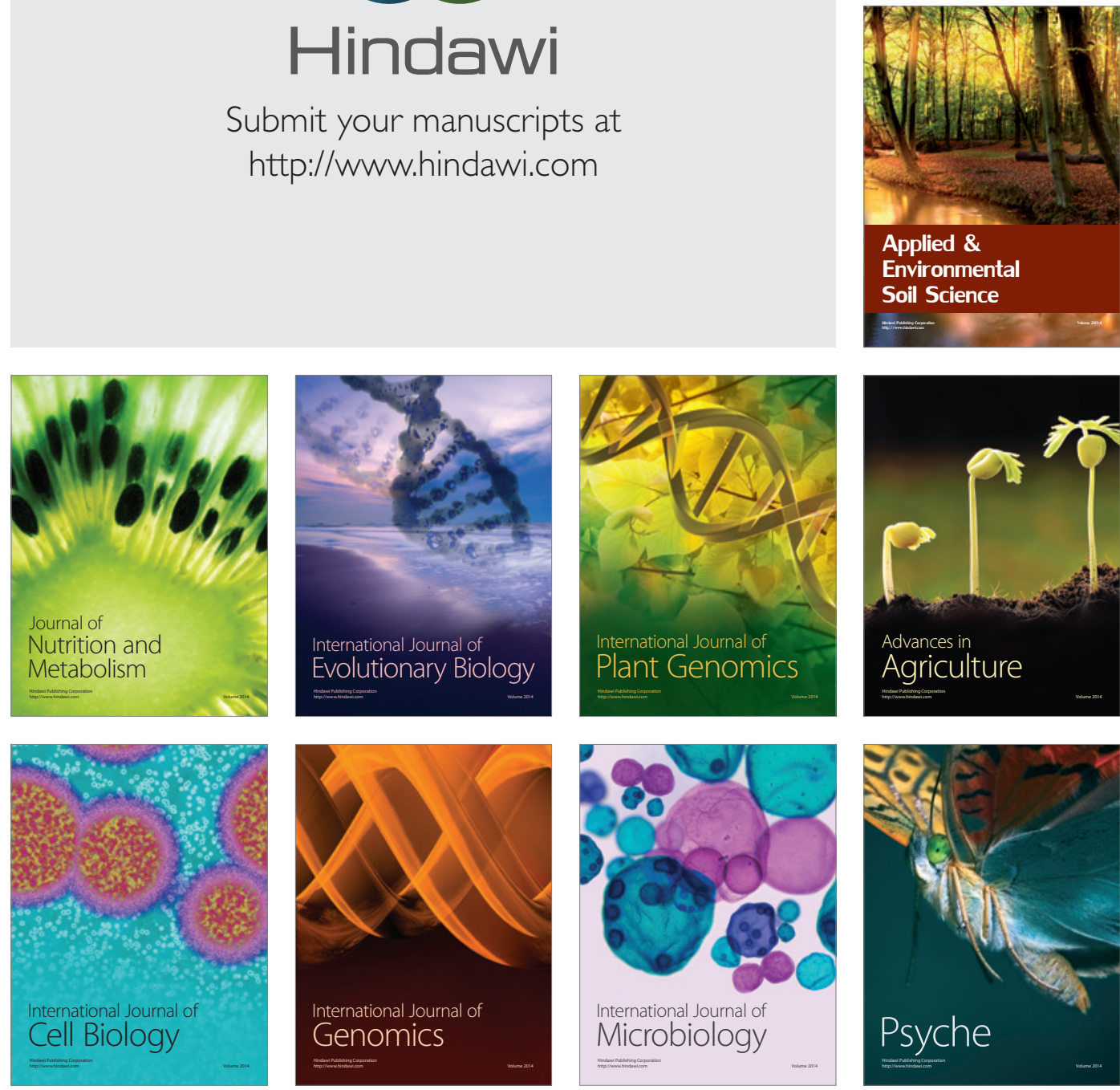
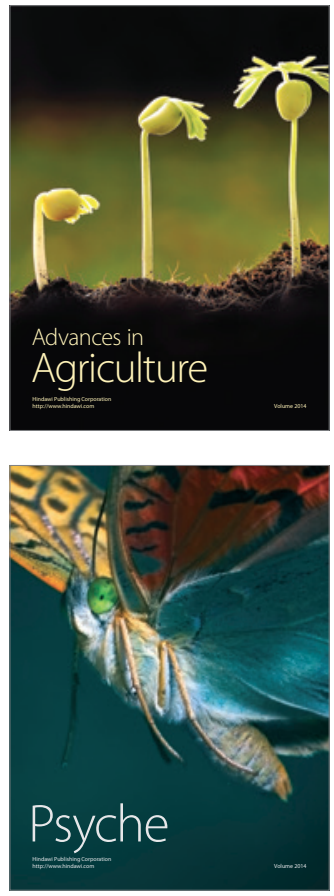